UDK 376-056.26/.36-053.4(497.11)

$373.2(497.11)$

doi: $10.5937 /$ bastina31-34262

Originalan naučni rad

\author{
Biljana S. JEREMIĆ* \\ University in Novi Sad, Faculty of Education in Sombor \\ Živorad M. MILENOVIĆ** \\ Univeristy in Priština - Kosovska Mitrovica, \\ Faculty of Teacher Education
}

\title{
EDUCATORS' PERCEPTIONS REGARDING THE INCLUSION OF EXPERTS OF VARIOUS PROFILES INTO THE TEAM FOR INCLUSIVE EDUCATION
}

\begin{abstract}
The past decade has witnessed the expansion of educators' competencies and their larger concern for children with developmental delays, i.e. inclusive education. The inclusion of developmentally delayed children into education is determined by the following: early detection of developmental conditions, timely intervention, an individualized education plan (IEP) and its practical application. The IEP is developed and implemented by the inclusive education team. The team members responsible for the development of the IEP for children with developmental delays in regular preschool education are: parents or caregivers, teachers and educators, early childhood professionals, personal assistants for developmentally delayed children, special education teachers or dialectologists, pedagogical assistants and other professionals. The goal of this research was to determine educators' opinion about the necessity of an early intervention as well as about the application of the IEP and the involvement of professional support in inclusive kindergarten programmes and practice. The sample was comprised of 70 early childhood educators with experience in teaching children with developmental delays. The research results showed that the participants were predominantly inclined towards the involvement of a music pedagogue into inclusive kindergarten education (51 of them or $71 \%)$. Therefore, this paper analyses the possibilities of supporting children with developmental delays through music teaching classes.
\end{abstract}

Key words: children with developmental delays, individualized approach, IEP.

* Associte Professor, mrbiljana@gmail.com

** Associate Professor, zivorad.milenovic@pr.ac.rs 


\section{INTRODUCTION}

Early detection and timely intervention are of crucial importance when it comes to the issue of developmental delay in children. A modern educator is expected to recognise atypical patterns of behaviour in children and thus enable early intervention. The necessity to involve professional teams in early childhood interventions has been emphasised by numerous authors (Andrejević 2005; Cvijetić 2014). A recently increased interest in early intervention is closely related to the discoveries made in the field of neurobiology and in developmental theories, which have proven that children's development and academic achievement benefit significantly from their early experiences and their stimulation. Namely, the majority of permanent connections formed in the brain are created in early childhood, when the brain is extremely adaptable and susceptible to external stimuli, which means that any detected deviations and conditions may be either remedied or alleviated. The early intervention programme is also conditioned by various international documents that guarantee a range of rights to all children, including children with developmental delays, such as the right to high-quality education, health and social welfare, participation in social activities, etc. (Milenovic et al. 2020; Popović et al. 2016; Ljubojević 2013). These rights are implemented in the legislation of numerous countries in the world and enable children with developmental delays and their families to access support services, so that they can be better involved in various activities with children without these delays and thus improve the quality of their own lives (Cvijetić 2014: 315).

The importance and application of the Individualised Education Programme (IEP) for children with developmental delays is discussed differently by many authors (Đuković et al. 2020; Vujačić et al. 2019; Milenović 2013; Ilić 2010). Its importance is proved by the fact that it is required by the law. According to Article 3 of the latest Rulebook on detailed instructions for determining the right to an individual educational plan, its application and evaluation from 2018, the IEP should be adapted to a child's educational needs. Therefore, there are three different IEPs. The IEP1 sets out the services and supports necessary for preschool-age children. It is an individualised education programme that determines the goal of support, adaptation and improvement of preschool education physical space, adaptation of teaching and educational methods in a preschool group, the order in which to apply these methods and the persons who give support. The other two IEPs (IEP2 and IEP3) are related to primary and secondary school education. The IEP1 cherishes an interdisciplinary approach, destigmatisation of children with developmental delays in inclusive practices and peers' evaluation of inclusive education. The IEP significantly influences the development of children with developmental delays. The crucial role 
is the one played by the preschool teacher, who is frequently the coordinator of the inclusive team, as well (Kojić et al. 2012). Preschool teachers should have the competencies they gain during their lifelong learning, which are related to the IEP from both theoretical and practical point of view.

The Rulebook offers explicit instructions for determining one's right to the individualised education plan, its application and evaluation (Official Gazette $R S$, No 74/2018). The right to the IEP is granted to a child or student who needs some additional support in education because they have trouble participating in regular teaching activities and achieving their academic improvement and success. This particularly refers to the problems related to the achievement of general educational results, especially if a child or a student: a) has trouble studying (caused by specific study problems or the problems in behaviour and emotional development); b) has developmental delays or disabilities (physical, motor, sensory, intellectual and multiple delays, or the problems pertaining to autism); c) originates from or lives in a socially disadvantaged environment (social, economic, cultural and language poverty, or a prolonged stay in healthcare or social institutions); and d) is entitled to this type of educational support for some other reasons. The achievement of the right to the IEP is conditioned by several factors, the most important being the parents' consent and the preschool teacher's qualifications.

The paper further analyses the examples of the support to the children with developmental delays that the music pedagogue provides through various music class activities: singing, playing, listening to music and music games. This approach is justified by the new preschool curriculum framework Years of Ascent. This preschool programme insists on children's equal rights and possibilities to learn and develop through art, as well (Official Gazette RS, No 88/17 и $27 / 18$ - state law).

\section{METHOD}

The goal of this research was to identify educators' opinion about the necessity of early intervention, analyse the application of the IEP and the support offered by experts of various profiles in preschool inclusive education, as well as to apply obtained results in future modifications of the practical methods aimed at achieving optimal inclusive preschool education.

\section{Sample}

The sample was comprised of 70 preschool teachers from Kikinda, Sombor, Zrenjanin and Belgrade. All of the participants had already had experience in teaching children with developmental delays and had been involved in creating pedagogical profiles and the IEPs for these children. 


\section{Research techniques and procedures}

The survey technique was used in the research. The survey provided insights into the respondents' opinion about the major topics of the research. The method used in the research was the descriptive method. The main research instrument was the Questionnaire for preschool teachers, which was adapted to meet the research goals. Prior to devising the Questionnaire, a preliminary study was conducted with 20 preschool teachers. The Questionnaire contained 12 carefully selected, clearly and adequately presented statements. The Questionnaire also had some empty space in which the respondents could write their comments.

\section{THE RESULTS OF THE RESEARCH}

Table 1 show the results obtained in the conducted research that studied the preschool teachers' opinion about early recognition and identification of preschool children's developmental delays. The research also investigated the necessity of early intervention, as well as the creation and application of the IEP in the inclusive education team. The presented research findings demonstrate that the cumulative results of the frequency study, AC, $\chi 2$ test, contingency coefficient and percentage indicate statistically significant differences in the preschool teachers' responses $(\mathrm{p}=.000)$, with the exception of the responses to question number 10 . The value of the contingency coefficient shows that there is a generally average connection between the phenomena examined through 12 (twelve) different statements.

Table 1. Preschool teachers' opinion regarding the involvement of the music pedagogue into the inclusive team

\begin{tabular}{|c|c|c|r|r|r|c|c|c|c|c|c|c|}
\hline Statement & $\mathrm{f} 1$ & \multicolumn{1}{c|}{$\%$} & $\mathrm{f} 2$ & \multicolumn{1}{c|}{$\%$} & $\mathrm{f} 3$ & \multicolumn{1}{c}{$\%$} & $\Sigma$ & $\mathrm{AC}$ & $\chi^{2}$ & $\mathrm{df}$ & $\mathrm{Cmax}$ & $\mathrm{C}$ \\
\hline 1. & 38 & 54.28 & 5 & 7.15 & 27 & 38.57 & 70 & 2.15 & 24.200 & 2 & .81 & .50 \\
\hline 2. & 36 & 51.43 & 21 & 30 & 13 & 18.57 & 70 & 2.33 & 11.686 & 2 & .81 & .37 \\
\hline 3. & 40 & 57.14 & 5 & 7.15 & 25 & 35.71 & 70 & 2.21 & 26.429 & 2 & .81 & .52 \\
\hline 4. & 37 & 52.86 & 25 & 35.71 & 8 & 11.43 & 70 & 2.41 & 18.200 & 2 & .81 & .45 \\
\hline 5. & 43 & 61.43 & 20 & 28.57 & 7 & 10 & 70 & 2.51 & 28.486 & 2 & .81 & .53 \\
\hline 6. & 46 & 65.71 & 11 & 15.72 & 13 & 18.57 & 70 & 2.47 & 33.114 & 2 & .81 & .56 \\
\hline 7. & 48 & 68.57 & 13 & 18.57 & 9 & 12.86 & 70 & 2.56 & 39.457 & 2 & .81 & .60 \\
\hline 8. & 51 & 72.86 & 7 & 10 & 12 & 17.14 & 70 & 2.56 & 49.743 & 2 & .81 & .64 \\
\hline 9. & 37 & 52.86 & 23 & 32.86 & 10 & 14.28 & 70 & 2.39 & 15.629 & 2 & .81 & .42 \\
\hline 10. & 31 & 44.29 & 21 & 31 & 18 & 25.70 & 70 & 2.19 & 3.971 & 2 & .81 & .23 \\
\hline 11. & 36 & 51.43 & 19 & 27.14 & 15 & 21.43 & 70 & 2.30 & 10.657 & 2 & .81 & .36 \\
\hline 12. & 54 & 77.14 & 6 & 8.58 & 10 & 14.28 & 70 & 2.63 & 60.800 & 2 & .81 & .68 \\
\hline
\end{tabular}


Statement number 1 , If I detect certain atypical developmental patterns in a child, I immediately inform preschool professionals and parents about that, was answered positively by 38 (54\%) preschool teachers. The majority of them first informed the preschool professionals and then the parents. The preschool teachers who responded that they addressed preschool professionals only occasionally or never stated that they did not consider themselves competent enough and that they were discouraged by parents' negative reactions.

Statement number 2, Early detection of developmental issues has an effect on the child's ability to function properly in later years, was answered positively by 36 (51\%) preschool teachers. The rest of the respondents selected either "occasionally" or "no" as their answers. The comments of those preschool teachers who responded positively were based on the latest neurobiological models of children's development, especially the development of the synapses and neurone connections (the knowledge acquired in seminars and from the study of the recommended materials in the field). The comments provided by the preschool teachers whose answer was "occasionally" were related to the type and level of the developmental delay. They believed that early intervention could be effective only in less serious cases of this impairment. The preschool teachers whose answer was "no" referred to the biological aspects of developmental delays and thought that these children's ability to function properly could not be improved significantly unless experts in defectology were included in regular educational groups.

Statement number 3, The IEP motivates children to develop their biological potentials to the greatest degree possible, was answered positively by 40 (57\%) preschool teachers. 5 (7\%) respondents answered "occasionally" and $25(36 \%)$ answered "no". The preschool teachers whose answers were "occasionally" and "no" explained their responses similarly as the previous one: they did not believe that the goals established by the IEP could be accomplished without the support of experts in defectology and without additional training of the members of the inclusive team.

Statement number 4, I frequently apply the individualised programme in teaching children, was answered in the following way: 37 (53\%) respondents said "yes", 25 (36\%) of them answered "occasionally" and 8 (11\%) preschool teachers responded "no". The respondents commented that they frequently applied the individualised programme in teaching children since even children with typical patterns of behaviour differed in many ways. Therefore, this approach to teaching offered equal opportunities to children to develop in accordance with their own abilities, interests and needs. This approach proved to be beneficial for the children with developmental delays, as well, because it was applied in the activities performed in small groups and accompanied with the peer support. 
Statement number 5, I need the pedagogue's support in planning and programming the IEP, was responded in the following manner: 43 (61\%) respondents said "yes", 20 (29\%) preschool teachers said "occasionally" and 7 (10\%) said "no". The comments provided by the respondents show that the majority of the preschool teachers needed the support of the pedagogue when teaching children with developmental delays, but that they seldom got it due to a small number of employed pedagogues in preschool education and because of their insufficient knowledge about the problems of the children with developmental delays.

Statement number 6, I need the support of the psychologist in devising the curricula for teaching children with developmental delays, was answered positively by $46(65 \%)$ of the respondents, while $11(16 \%)$ of them said "occasionally" and 13 (19\%) answered "no". The respondents' comments resemble those provided for the previous statement, the only difference being that the respondents believed that psychologists were more competent for offering support in teaching children with developmental delays.

The distribution of the responses for the statement number 7, The preschool physical education teacher has to be a member of the inclusive team, was the following: 48 (69\%) of the respondents provided positive attitudes, 13 (19\%) answered "occasionally" and 9 (13\%) said "no". According to the respondents' comments, the preschool physical education teacher should help with the exercises for the improvement of the motor skills of the children with developmental delays, which would be beneficial for their general condition.

Statement number 8 , The preschool music professional has to be a member of the inclusive team, was responded in the following way: 51 (73\%) of the respondents answered "yes", 7 (10\%) said "occasionally" and 12 (17\%) said "no". The majority of the respondents commented that musical activities and movement to music were beneficial for the children with developmental delays and that the music pedagogue had to be involved in the inclusive education team.

Statement number 9, The preschool art professional has to be a member of the inclusive team, was responded in the following manner: 37 (53\%) of the respondents said "yes", 23 (33\%) of them said "occasionally" and 10 (14\%) said "no".

Statement number 10, Parents always attend the meetings of the inclusive team, was answered positively by 31 (44\%) respondents. 21 (31\%) of the preschool teachers said "occasionally" and 18 (26\%) of them provided a negative answer. The respondents commented that parents should always attend the meetings of the inclusive education team, demonstrate a greater interest in their children's development and progress, practice exercises recommended by dialectologists and medical experts and initiate additional meetings and discussions.

Statement number 11, Parents of developmentally delayed children is frequently invited to communicate with teachers in person, was commented in the following way: 36 (51\%) of the respondents provided a positive answer, 19 (27\%) 
of them said "occasionally" and 15 (21\%) answered "no". The majority of the respondents assumed that communication with parents in person contributed to their developing a greater sense of trust and empathy towards their children and families, which is the reason why this kind of parent-teacher communication should be encouraged. Parents should be advised not to develop the sense of guilt or denial of the real situation. They should be informed that their children are accepted and treated equally as other children attending the kindergarten.

Statement number 12, The experts in defectology provide the greatest degree of support to the inclusive team, was commented positively by 54 (77\%) of the respondents, while 6 (9\%) of them answered "occasionally" and 10 (14\%) of the respondents provided a negative answer. The respondents mainly stated that the inclusive education team could not function without the involvement of dialectologists, who should coordinate the activities of inclusive teams. The majority of the respondents emphasized that dialectologists should be included into teaching and individual activities with the developmentally delayed children within their regular groups.

As regards the support provided by various preschool professionals (art, physical education and music), the largest percentage of the respondents (73\%) concluded that the support of the music pedagogue was the most significant one. Therefore, this paper analyses and discusses this type of support in preschool inclusive education. It should be also added that the greatest percentage of the respondents (77\%) considered the experts in defectology to be the most important persons for preschool activities that include the children with developmental delays.

\section{CONCLUSION AND PEDAGOGICAL IMPLICATIONS}

The research findings prove that the majority of preschool teachers believe that all participants in inclusive education need support. Preschool teachers need professional support in order to provide high-quality education to children with developmental delays from their early childhood. Preschool teachers are expected to have good knowledge of children's typical patterns of development so that they can recognize developmental issues in certain children. The respondents identify early intervention and the support provided by a whole range of experts as crucial for inclusive education. Support is undoubtedly necessary in inclusive education, both from the rhetorical and pragmatic point of view. Parents also need support that will help them realise and accept developmental delays in their children, and consequently act in the proper manner so that their children be accepted for early intervention. Moreover, since parents enroll their children with developmental delays to go to regular kindergartens, 
it means that these preschool institutions need adequate professional support from a team of experts in various fields. Parents should be encouraged to enroll their children to attend either regular preschool (with the adapted IEP applied) or special education school (with the altered IEP applied). The results of this research are in agreement with numerous studies published in leading world journals (Väyrynen, Paksuniemi 2020; Grynova, Kalinichenko 2018; Zundana Fraser, Bain 2016).

This research may contribute to further studies in the field that can examine the following: the topics related to early recognition of developmental issues in children by preschool teachers, the comparison of the number of children with developmental delays accepted for early intervention and the total number of children with developmental delays, application and results of the IEP, the involvement of experts and professionals into inclusive teams These findings are confirmed by some other research conducted in the Republic of Serbia and in the world (Kovačević, Radovanović 2021; Jeremić, Milenović, 2020; Farias et al. 2017). Children with developmental delays can be granted adequate support only by timely, professional and overall intervention performed by expert teams. The problems that children with developmental delays encounter can be overcome by applying systematic measures. This will secure a flexible environment essential for their optimal development.

\section{REFERENCES}

Andrejević 2005: Danica Andrejević, Rana intervencija u Evropi - trendovi u 17 evropskih zemalja. Beograd: Zadužbina Andrejević.

Cvijetić 2014: Marija Cvijetić, Rana intervencija kod dece sa smetnjama u razvoju. U Tamara Grujić (ur). Tematski zbornik radova s naučno-stručne konferencije Metodički dani Kompetencije vaspitača za društvo znanja (314-319). Visoka škola strukovnih studija za obrazovanje vaspitača u Kikindi.

Đuković i sar. 2020: Anđela Đuković, Ivana Mrvoš i Ivica Radovanović, Vaspitanje i obrazovanje zasnovano na umetnosti kao inkluzivno vaspitanje i obrazovanje. Inovacije u nastavi - časopis za savremenu nastavu 33(2), 1-14.

Farias et al 2017: Cláudio Farias, Peter Andrew Hastie, Isabel Mesquita 2017: Towards a More Equitable and Inclusive Learning Environment in Sport Education: Results of an Action Research-Based Intervention. Sport, Education and Society 22(4), 460-476.

Grynova and Kalinichenko 2018: Maryna Grynova, Ityna Kalinichenko, Trends in Inclusive Education in the USA and Canada. Comparative Professional Pedagogy 8(2), 28-34.

Ilić 2010: Mile Ilić, Inkluzivna nastava. Univerzitet u Istočnom Sarajevu, Filozofski fakultet na Palama.

Jeremić Milenović 2020: Biljana Jeremić i Živorad Milenović, Društveni kontekst nastave muzičke kulture u funkciji negovanja tradicionalnog narodnog stvaralaštva Srba. Baština 35(52), 441-461.

Knapp 2011: David Knapp, The Inclusive World of Music: Students with Disabilities and Multiculturalism. General Music Today 25(1), 41-44. 
Kojić i sar. 2012: Miroslava Kojić, Zagorka Markov, Branka Samardžić, Kompetencije vaspitača sa gledišta individualnog obrazovnog plana u kontekstu inkluzije. Zbornik VŠSSOV, (2), 28-42.

Kovačević i Radovanović 2021: Jasmina Kovačević i Vesna Radovanović, Komunikacija gluvih zasnovana na oralnoj metodi. Baština 31(54), 395-410.

Ljubojević 2013: Danijela Ljubojević, Individualizacija u nastavi stranog jezika na ranom uzrastu Inovacije u nastavi - časopis za savremenu nastavu 26(1), 54-61.

McFerran 2011: Katrina McFerran, Music Therapy with Bereaved Youth: Expressing Grief and Feeling Better. Prevention Researcher 18(3), 17-20.

Milenović et al 2020: Živorad Milenović, Biljana Jeremić and Danijela Sudzilovski, Perceptions Of Pre-Service Primary School Teachers Regarding the Application of Interactive Educational Software in Classroom Teaching. Inovacije u nastavi - časopis za savremenu nastavu 33(3), 98-110.

Milenović 2013: Živorad Milenović, Nastavnik u inkluzivnom nastavi. Beograd: Zadužbina Andrejević.

Popović i sar. 2016: Daliborka Popović, Miloš Lazović and Žarko Milosavljević, Podrška razvijanja darovitosti u školskoj praksi. Inovacije u nastavi - časopis za savremenu nastavu 29(3), 73-83.

Väyrynen and Paksuniemi 2020: Sai Väyrynen, Merja Paksuniemi, Translating Inclusive Values into Pedagogical Actions. International Journal of Inclusive Education 24(2), 147-161.

Vujačić i sar. 2019: Milja Vujačić, Rajka Đević, Ivana Đerić, Saradničko učenje u kontekstu inkluzivnog obrazovanja. Inovacije u nastavi - časopis za savremenu nastavu, 32(3), 1-12.

Zundana Fraser and Bain 2016: Lucia Zundana Fraser, Alan Bain, the Role of Collaboration in a Comprehensive Programme Design Process in Inclusive Education. International Journal of Inclusive Education 20(2), 136-148.

*** Правинника о ближим уйуйстивима за уйврђивање ирава на индивияуални образовни йлан, њеїову иримену и вредновање из 2018. „Сл. йласник РС“, бр. 74/2018.

*** Правилник о основама програма преАшколског васпитања и образовања. 2018. „Службени гласник РС“, бр. 88/17 и 27/18 - Ар. Закон. 


\author{
Биьана С. ЈЕРЕМИЋ \\ ЖивораА М. МИАЕНОВИЋ
}

\title{
ПЕРЦЕПЦИЈЕ ВАСПИТАЧА О УКЬУЧИВАҢУ СТРУЧЊАКА РАЗАИЧИТОГ ПРОФИАА У ТИМ ЗА ИНКАУЗИВНО ОБРАЗОВАҢЕ
}

\section{Резиме}

Компетенције васпитача последњу Аеценију прошириле су се и усмериле ка деци са сметњама у развоју, односно на инкцузивно васпитање и образовање. У области инкцузије Аеце са сметњама у развоју важну умогу имају: рано препознавање поремећаја, правовремена интервенција, индивидуални образовни план (ИОП) и његова примена у пракси. За израду и примену ИОП-а наАлежан је тим за инкцузивно образовање. Чланови тима за израАу ИОП-а за дете са сметњама у развоју у редовном вртићу су: родитељи или старатељи деце, васпитач, стручни сарадник преАшколске установе, мични пратилац детета, дефектолог, пеАагошки асистент и Аруге особе према потреби. Кьучне речи: деца са тешкоћама у развоју; индивидуамизован приступ; музички педагог. Многи аутори са размичитих аспеката говоре о значају и примени Индивидуалног образовног програма (ИОП) за Аецу са сметњама у развоју (АеАај 2012; Марков и Којић, 2012; Петковић, 2012). Колико је значајан, показује и чињеница аа је предвиђен законским прописима. Према члану 3. најновијег Правилника о ближим уйуйстивима за уйврђивање ирава на индивияуанни образовни йлан, њеіову иримену и вредноване из 2018, ИОП се израђује према образовним потребама Аетета. У зависности оА тога постоје три размичита ИОП-а, оА којих преАшколска установа доноси ИОП1 који је прилагођени програм васпитања и учења у коме се планира циь пружања подршке, прилагођавање и обогаћивање простора и услова у којима се учи, прилагођавање метода раАа и среАстава током активности у васпитној групи, њихов распореА као и мица која пружају подршку. Остала Ава (ИОП2 и ИОПЗ) Аоносе основна и среАња школа. ОвАе се тежиште ставља на интердисциплинарни приступ, Аестигматизацију деце са сметњама у развоју у инккузивном процесу и процена вршњака о инклузивном васпитању и образовању. ИОП има важну улогу у подстицању развоја преАшколске деце са сметњама у развоју. У примени индивидуалног образовног програма, значајну улогу има васпитач, који је често и координатор тима за инккузивно образовање (Којић и сар. 2012). Уочьиво је Аа Аа васпитачи требају имати компетенције које стичу у оквиру цеможивотног учења, а односе се на ИОП са теоријског гледишта и практичне примене.

Правилником су дата ближа упутства за утврђивање права на индивидуални образовни план, његову примену и вредновање (СА. гласник РС, бр. 74/2018). Право на ИОП има Аете и ученик, који има потребу за Аодатном подршком у образовању и васпитању, због тешкоћа у приступању, укьучивању, учествовању, или напредовању у васпитно-образовном, или образовно-васпитном раду. Посебно ако те тешкоће утичу на остваривање општих исхода образовања и васпитања, а нарочито ако Аете, односно ученик: а) има тешкоће у учењу (због специфичних сметњи учења, или проблема у понашању и емоционалном развоју); б) има сметње у развоју, или инвалидитет (телесне, моторичке, чулне, интелектуанне, вишеструке сметње, или сметње из спектра аутизма); в) потиче, односно живи у социјално нестимулативној средини (социјално, економски, културно, језички сиромашној средини, или дуготрајно борави у зАравственој, односно социјалној установи); и г) из Аругих размога остварује право на подршку у образовању. Аа ми ће права детета на ИОП бити остварена зависи оА низа фактора, а јеАан веома важан је сагласност родитеља да дете буде обухваћено планом и оспособњеност васпитача. 
Циь истраживања је идентификација процена васпитача о потреби спровођења процеАура раних интервенција за подршку инкмузији, анализа и примена ИОП-а и подршка стручњака разних профика у реализацији инклузивног васпитања и учења у дечјим вртићима, те примена добијених резултата у дањим модификацијама практичних метода за постизање оптимизације инклузије у дечјем вртићу. Узорак чини 70 васпитача запослених у Аечјим вртићима на подручју Кикинде, Сомбора, Зрењанина и Београда. Сви васпитачи обухваћени истраживањем имају претходно искуство у раду са децом са сметњама у развоју и учествовали су у изради педагошких профила за ову децу и ИОП-а. Техника коју смо користити у овом истраживању је анкетирање. Анкетом смо идентификовали мишьења васпитача о главним темама везаним за истраживање. Метода коришћена у истраживању је Аескриптивна. Основни инструмент истраживања је Упитник за васпитаче, који је прилагођен овом истраживању. Пре конституисања Упитника спроведено је пилот истраживање на узорку оА 20 васпитача. Сам Упитник саставьен је оА мисте са 12 пажьиво изабраних, јасно и правилно формулисаних питања, конструисаних у циљу спровођења овог истраживања. Испитаници су у Упитнику имали простор преАвиђен за доАатни коментар.

Налази истраживања показују Аа већина васпитача сматра Аа је подршка потребна свим учесницима инкцузије. Васпитачима је потребна стручна поАршка, како би они могли деци са сметњама у развоју да омогуће што квалитетније васпитање и образовање од најранијег периода. Васпитачи треба Аобро Ао познају типични развој, у циљу Аа препознају развојне тешкоће код Аеце. Рана интервенција, уз широк Аијапазон стручњака размичитих струка, такође се коА испитаника идентификује као потреба за што квалитетнијем инкцузивном васпитању и образовању. Подршка је у инклузији незаобилазна, како у реторичком, али најпре у прагматичном смислу и деловању. Исту прво треба Аати родитељима, како би они након сазнања у правом тренутку прихватили развојну сметњу детета и предузели све мере, Аа би оно било обухваћено раном интервенцијом. Такође ако родитеь уписује своје дете са развојним сметњама у реАовни вртић или школу, онда је и тим установама потребна оАговарајућа и професионална подршка од стране стручњака Аефектолошке и медицинске струке. Родитеьу треба Аати подршку и усмерити га Аа дете упише у редовну (примена прилагођеног ИОП-а), или у школу за ученике са сметњама у развоју (примена измењеног ИОП-а).

Ово истраживање може Аа послужи као идеја истраживачима Аа у блиској будућности испитају: проблематику раног препознавања развојних тешкоћа оА стране васпитача, обухваћеност Аеце са сметњама у разоју раном интервенцијом у односу на број Аеце која имају развојне сметње, примену и ефекте примене ИОП-а, укьученост стручњака различитих струка у инкцузивне тимове. Правовременом, професионалном и целовитом подршком, са установьеним процедурама и адекватним средствима оА стране разних стручњака, могуће је обезбедити подршку Аеци са сметњама у развоју. Системским мерама превазићи ће се проблеми са којима се Аеца са сметњама у развоју срећу и обезбеАити фмексибилно окружење за њихов оптимални развој.

Кьучне речи: Аеца са тешкоћама у развоју, индивидуализован приступ, ИОП.

РаА је предат 5. октобра 2021. године, а након мишьења рецензената, одмуком одговорног уредника Башӣине, одобрен за штампу. 